\title{
CHARACTERIZATION OF THE PLASMIDIC OR CHROMOSOMAL CPE GENE AND METABOLIC ACTIVITIES IN CLOSTRIDIUM PERFRINGENS ISOLATES FROM FOOD IN SAN LUIS - ARGENTINA
}

\author{
Mariana Georgina Coriglianoㄹ, Ana María Stefanini de Guzmán ${ }^{1}$, Patricia Virginia Stagnitta² \\ ${ }^{1}$ General Microbiology, Area of Microbiology, Department of Biochemistry and Biological Sciences, Faculty of Chemistry, Biochemistry and \\ Pharmacy, San Luis National University, Argentina \\ ${ }^{2}$ Biological Chemistry, Area of Microbiology, Department of Biochemistry and Biological Sciences, Faculty of Chemistry, Biochemistry and Phar- \\ macy, San Luis National University, Argentina
}

\begin{abstract}
SUMMARY
Food poisoning and non-food poisoning illnesses due to $C$. perfringens (by enterotoxin production) have been associated to chromosomal or plasmidic location of the cpe gene, respectively. Clostridial pathogenicity has been correlated to protease and azoreductase production.

The aim of this work was: i) to assess the sanitary-hygienic quality of dehydrated soups (100 samples) consumed in San Luis - Argentina; ii) to verify the presence of $C$. perfringens in these food products using the "Most Probable Number" method (MPN) and plate-counting methods; iii) to characterise enterotoxigenicity in strain isolates by RPLA; iv) to determine the chromosomal or plasmidic location of the cpe gene in enterotoxigenic strains previously isolated from food in our lab, using PCR; v) to correlate chromosomal cpe and spore heat-resistance; vi) to compare protease activity in cpe+ and cpe-strains; and vii) to compare azoreductase activity in cpe+ and cpe-strains. Twenty-six isolates had a count a 3-43 bacteria g ${ }^{-1}$ count using MPN; 7.7\% exceeded the Argentine Food Code (CAA) limit. All isolates showed protease activity: enterotoxigenic isolates had higher protease activity than non-enterotoxigenic isolates. All isolates showed azoreductase activity: enterotoxigenic isolates had higher activity and shorter reducing times. Enterotoxigenic isolates showed chromosomal location for the gene responsible for the enterotoxin.
\end{abstract}

Key words: clostridium perfringens, enterotoxin, protease, azoreductase, food

Address for correspondence: P. V. Stagnitta, Area Química Biológica. Departamento de Bioquímica y Ciencias Biológicas. Facultad de Química, Bioquímica y Farmacia. Universidad Nacional de San Luis, Chacabuco y Pedernera, 5700-San Luis, Argentina. E-mail: pvstag@unsl.edu.ar

\section{INTRODUCTION}

Clostridium perfringens are Gram-positive anaerobic bacteria widely spread in the environment, soil and water, and which can usually be found in the gastrointestinal tract of humans and animals (1-5). It is an important pathogen causing illnesses such as, among others, human enteritis and enterotoxemia in domestic animals $(1,2,4,6,7)$. C. perfringens can be transmitted through food, particularly by cooked meats that are allowed to cool slowly and are eaten some time later (8-10). In many cooked foods, the presence of spores can be unavoidable because spores are heatresistant and are frequently found in raw foods.

These bacteria produce at least 17 toxins, including the $C$. perfringens enterotoxin (CPE) $(3,4,11,12)$, which is known to cause human food poisoning. C. perfringens intoxication can be due to ingestion of food containing an enterotoxigenic strain in a concentration $\geq 10^{5} \mathrm{CFU} / \mathrm{g}(13,14)$. In vivo, enterotoxin production is associated to sporulation in the intestine $(3,15$, 16), while an adequate culture medium is needed for in vitro production $(13,17)$. Vegetative cells that reach the intestine and undergo sporulation produce $\mathrm{CPE}$, which in turn is responsible for clinical symptoms. This toxin-infection is characterized by nausea, diarrhea, abdominal pain and gases, 6 to $12 \mathrm{hrs}$ after the intake of contaminated food. Recovery is fast, usually within 12 hrs $(3,18-21)$.

C. perfringens has been classified to five types (A, B, C, D and E) based on production of four main toxins $(\alpha, \beta, \varepsilon$ and $\iota)(11,12$, 21-23). These toxins can be determined by serological methods or by molecular methods such as PCR $(2,13,24)$. Because these are spore-forming bacteria, they are very resistant to the action of external agents, which in turn favours their distribution (4).

Strains type A carry the cpe gene in 5-8\% of the global population $(3,21-23,25,26)$. C and D strains can also carry cpe and produce CPE $(4,23)$. The cpe gene encoding the CPE toxin can be located in the plasmid or in the chromosome of $C$. perfringens $(11,22,27,28)$. It is accepted that $C$. perfringens strains associated to food poisoning carry their $c p e$ gene in the chromosome; while $C$. perfringens strains causing illnesses not transmitted through food, such as antibiotic-related diarrhea and sporadic diarrhea, carry the cpe gene in a plasmid $(18,26,29$, 30). In opposition to the description above, Tanaka et. al (2003) studied an outbreak in which 90 of 192 individuals showed symptoms of diarrhea and abdominal pain, within an incubation period of $15.5 \mathrm{hrs}$. Boiled peas were suspected to be the vehicle for $C$. perfringens because they were cooked in large quantities, slowly cooled and inadequately reheated before the meal was 
served. It should be noted that the location of the cpe gene in this study was concluded to be plasmidic, as determined by Pulse Field Gel Electrophoresis (PFGE).

Spores from strains containing the chromosomal cpe gene are more resistant to heat than spores from strains with the gene in a plasmid (31). Heat resistant spores survive the cooking process and continue to cause food poisoning; this may explain why most of the strains generating food poisoning have their cpe gene located in the bacterial chromosome $(29,32)$.

Microbial enzymes are the major cause of food quality decay and putrefaction (33). Protease formation has been related to food poisoning and to pathogenicity in a great number of clostridia, including C. perfringens (34). Casein and azocasein are different compounds used as protease substrates. Poilane and Zarnowski have studied extracellular proteolytic enzyme production in C. difficile and Histoplasma capsulatum, respectively. Also, azocasein was used by Brock to study the proteolytic activity of the microflora in rumen (35-37). In addition to extracellular protease production (33, 38-41), C. perfringens synthesizes intracellular proteases (42).

C. perfringes is a commensal in the human low gastrointestinal tract $(4,5)$ that produces azoreductase, which catalyzes the reducing cleavage of colored azo-compounds (43). Azo-colored compounds represent a large group of chemical products widely used in the textile, pharmaceutical, food and cosmetic industries. These compounds are reduced by enzymes called azoreductases. Azoreductases are produced by intestinal bacteria and - to less extent - by enzymes from the microsomal and cytosolic fractions of the liver $(44,45)$. Some azo-compounds have been correlated to human gall bladder cancer, liver carcinomas, nuclear anomalies in experimental animals and chromosomal aberrations in mammal cells (46). It has been determined that several hydrolytic and reducing enzymes from $C$. perfringens such as azoreductase can be implicated in mutagenic or genotoxic metabolite production in the human intestinal tract, which constitutes an important virulence factor $(44,47,48)$.

The aims of the present work were: i) to establish sanitary hygienic quality in dehydrated soups comsumed in San Luis Argentina; ii) to determine the presence of $C$. perfringens in these products using the Most Probable Number method (MPN) and plaque counting methods; iii) to characterize enterotoxigenicity of isolated strains using the immunological RPLA method; iv) to determine plasmidic or chromosomal location of the cpe gene by PCR from enterotoxigenic strains previously isolated from food in our laboratory; v) to correlate the presence of cpe in the chromosome and heat-resistance of spores; vi) to compare protease activity between $c p e+$ and cpe-strains; and vii) to compare azoreductase activity between $c p e+$ and $c p e-$ strains.

\section{MATERIALS AND METHODS}

\section{Strains}

Two reference strains, NTCC 8798 cpe + and ATCC 3624 cpewere kindly supplied by Dr. Ronald G. Labbé from University of Massachusetts, USA. Fifteen enterotoxigenic strains were previously isolated from meat food, seasoning and spices. Twenty-six isolates from dehydrated soups.

\section{Samples}

One hundred dehydrated soup samples from local markets in San Luis City - Argentina were obtained and processed. One gram of each dehydrated soup sample was aseptically weighed and dissolved in $10 \mathrm{ml}$ of sterile $0.1 \%$ peptone water. Ten-fold dilutions were made transferring $1 \mathrm{ml}$ from the original suspension to tubes containing $9 \mathrm{ml}$ of sterile $0.1 \%$ peptone water.

\section{Determination of hygienic conditions of samples Total aerobic bacteria count:}

Agar medium for plate counts (Britania) was used. $10 \mathrm{ml}$ of sterile medium were plated on Petri dishes and $0.1 \mathrm{ml}$ of each dilution was seeded in duplicate by spreading over the medium surface with spatula. Inoculated media were incubated at $37^{\circ} \mathrm{C}$ and colony count performed after $48 \mathrm{hrs}$.

\section{Investigation of total coliforms and $\boldsymbol{E}$. coli}

Mac Conkey Broth (Merck) was used. One ml of each dilution was seeded in triplicate and incubated at $37^{\circ} \mathrm{C}$. Test readings were taken after $48 \mathrm{hrs}$. In order to confirm E. coli EC broth (Britania) was prepared. $0.1 \mathrm{ml}$ from each positive Mac Conkey tube was seeded and incubated at $45^{\circ} \mathrm{C}$ during $24 \mathrm{hrs}$.

\section{C. perfringens count}

Most Probable Number (MPN) in iron-milk medium: The iron-milk medium was prepared according to William et al. (49). One $\mathrm{ml}$ of each dilution were seeded in triplicate in tubes containing iron-milk medium and then incubated at $45^{\circ} \mathrm{C}$. Test readings were taken $16-18 \mathrm{hrs}$ after. Tubes showing tumultuous fermentation were considered as positive. Man's Table was used to determine MPN (50). Results were expressed as MPN per food gram $\left(\mathrm{MPN} \cdot \mathrm{g}^{-1}\right)$.

\section{Purification and identification of $C$. perfringens}

Differential agar medium for clostridia (Britania) was used. An inoculating loop load from a thioglycolate broth culture was seeded on a Petri dish and incubated at $37^{\circ} \mathrm{C}$ during $24 \mathrm{hrs}$ in anaerobic conditions. Black colonies were considered as positive. Suspicious black colonies were identified by Gram's stain in addition to the following biochemical tests: catalase, nitrate reduction, gelatin hydrolysis, starch hydrolysis, lecitinase and hemolysis.

\section{Strain Maintenance}

Strains were maintained in cooked meat medium and passed into thioglycolate broth or brain-heart infusion broth (BHI) (Britania) according to each assay.

\section{In vitro production of enterotoxin}

Strains cultured in BHI broth were obtained after 12-18 hrs at $37^{\circ} \mathrm{C}$ and further grown at $37^{\circ} \mathrm{C}$ during $10-12$ days in Tórtora medium (51) Modified (Tm) by Stagnitta et al. 2002 (13).

\section{Enterotoxin titration}

Reverse passive latex agglutination (RPLA) was used to determine enterotoxin levels in culture supernatants. The PET-RPLA kit (Oxoid), which has $2 \mathrm{ng} / \mathrm{ml}$ sensitivity, was used. Supernatants of CPE-positive and CPE-negative reference strains were used as controls. 
Correlation of the chromosomal location of the cpe gene and spore heat-resistance in enterotoxigenic strains.

Enterotoxigenic strains cultured in BHI broth were obtained after $12-18 \mathrm{hrs}$ at $37^{\circ} \mathrm{C}$. Sporulated cultures were obtained after incubation at $37^{\circ} \mathrm{C}$ during $10-12$ days in (Tm) medium. Cultures were heated at $80^{\circ} \mathrm{C}$ and $100^{\circ} \mathrm{C}$ for $10 \mathrm{~min}$, respectively. One ml of each Tm culture was incubated in $10 \mathrm{ml}$ of BHI in anaerobiosis over night $(31,52)$.

\section{Protease activity determination Kinetics}

In order to determine proteolytic activity of the strains in function of substrate concentration, a kinetic assay using the modified Domínguez and Cejudo method was performed to assess optimal azocasein (Sigma) concentration. One cpe+ and one cpe- strain were randomly chosen and used (53).

\section{Protease activity}

Based on the kinetic study, the assay conditions in tube 3 were the conditions of choice to study protease activity in $15 \mathrm{cpe}^{+}$ strains and 13 cpe-strains (53). One Enzymatic Activity Unit was defined as 1 Absorbance Unit increase per reaction time (Unit/ hour). Determination of protease specific activity was completed with the quantification of total proteins present in the supernatant using the Lowry method (54).

\section{Azoreductase activity determination}

Azoreductase activity in the supernatant was determined by discoloring the substrate Direct Blue 15 (Sigma) according to Raffi et al. $(44,55)$. A culture grown in anaerobiosis for $12 \mathrm{hrs}$ at $37^{\circ} \mathrm{C}$ was then centrifuged at $15000 \mathrm{xg}$ for $15 \mathrm{~min}$. Two $\mathrm{ml}$ of supernatant were taken under anaerobiosis and added with Direct Blue 15 to a final concentration of $100 \mu \mathrm{l} / \mathrm{ml}$. Tubes were monitored until Direct Blue 15 was completely reduced and discolored. Required times for total reduction was registered. Total protein concentration was determined using the Lowry method by taking a supernatant aliquot before incubating the supernatant with the susbstrate.

\section{Isolation and purification of DNA from Clostridium perfrin- gens}

Cultures were obtained in $10 \mathrm{ml}$ of BHI broth incubated anaerobically during $12 \mathrm{hrs}$ at $37^{\circ} \mathrm{C}$. A $0.2 \mathrm{ml}$ aliquot was taken and incubated anaerobically in $10 \mathrm{ml}$ of TGY broth (3\% trypticase, $2 \%$ glucose, $1 \%$ yeast extract, $0.1 \%$ cysteine) during $12 \mathrm{hrs}$ at $37^{\circ} \mathrm{C}(22)$. DNA extraction was performed as described previously (23) and quantification was done by absorption measurements at 280 and $260 \mathrm{~nm}$ using a Beckman UV-visible spectrophotometer DU Series 600. Finally, $10 \mathrm{ng} / \mu \mathrm{l}$ DNA dilutions were prepared.

\section{PCR assay for detection of the chromosome-located cpe gene \\ Simple cpe-IS1470 PCR assay for detection of the chromo- some-located cpe gene}

On the basis of recent studies describing the organization of the chromosomal cpe locus, Miyamoto et al. (21) have designed a primer pair that amplifies an $\sim 2.1 \mathrm{~kb}$ PCR product from the apparently conserved DNA region between the chromosomal cpe gene and the downstream insertion sequences IS1470 in type A isolate strains: 5'-CAGTCCTTAGGTGATGGA-3' (primer CPE4.5F) and 5'-AACTAAATAGGCCTATAAATACC-3' (primer IS1470F). PCR amplification was carried out by mixing 500-1000 ng of DNA with both primers at $1 \mu \mathrm{M}$ concentration each (Biodynamics), deoxynucleotide triphosphates (dNTPs) at $0.2 \mu \mathrm{M}$ each (Promega), $\mathrm{MgCl}_{2} 2 \mathrm{mM}$ (Promega) and $1.25 \mathrm{U}$ of Taq Polymerase (Invitrogen), in a $50 \mu 1$ final volume per reaction tube. Cycling was started with $5 \mathrm{~min}$ at $94^{\circ} \mathrm{C}$; followed by 33 cycles of: $30 \mathrm{sec}$ at $94^{\circ} \mathrm{C}, 60 \mathrm{sec}$ at $63^{\circ} \mathrm{C}$ and $180 \mathrm{sec}$ at $72^{\circ} \mathrm{C}$; and a final cycle of: $90 \mathrm{sec}$ at $94^{\circ} \mathrm{C}, 90 \mathrm{sec}$ at $60^{\circ} \mathrm{C}$ and $7 \mathrm{~min}$ at $72^{\circ} \mathrm{C}$. The Wen et al. technique was used, modifying polymerization temperature to $72^{\circ} \mathrm{C}$ due to use of Taq polymerase (22). Amplification was carried out in Perkin Elmer thermal cycler model PCR System 2000 . Results were determined by $1.5 \%$ agarose gel electrophoresis. Agarose was dissolved in 1X Tris-Borate buffer (TBE). Before gel solidification, $1 \mu \mathrm{l}$ ethidium bromide was added to reach $1.5 \mu \mathrm{g} / \mathrm{ml}$ final concentration. PCR samples were run in an electrophoresis apparatus (BioRad Power PAC 1000 Midicell EC3500) at $80 \mathrm{~V}$ during $50 \mathrm{~min}$, in $0.5 \mathrm{X}$ TBE buffer. Bands were viewed on a transilluminator (White-Ultraviolet transilluminator UVP Ultraviolet Products Upland Sigma) and photographs were taken with a Polaroid camera (Polaroid Gel Cam EPH5 0.85x Electrophoresis Hood).

\section{Single $\mathrm{dcm}$-cpe PCR assay for detection of the plasmid-located cpe gene}

On the basis of recent studies describing the organization of the plasmid-borne cpe locus, Miyamoto et al. (21) have designed a primer pair that amplifies an $\sim 3.3 \mathrm{~kb}$ PCR product from an apparently conserved DNA region in the plasmid and located between the up-stream dcm sequences and the cpe gene, in type A isolate strains:

5'-CTCAGAGTTAGGAGCTAGCCCAACCC-3' (primer MET$1.5 \mathrm{~F})$ and

5'-CCTAATATCCAACCATCTCC -3' (primer CPE-up). PCR amplification was run using both primers at a final concentration of $1 \mu \mathrm{M}$ each (Promega), in $50 \mu \mathrm{l}$ final reaction volume containing the other mix reagents and template in equal concentrations as in the chromosomal cpe PCR amplification. In addition, the same cycling conditions were applied here as described above (22). Amplification was carried out in a Perkin Elmer thermal cycler model PCR System 2000. Results were determined by $1.5 \%$ agarose gel electrophoresis. PCR samples were run at $80 \mathrm{~V}$ during $50 \mathrm{~min}$. Bands were viewed on a transilluminator and photographs were taken with a Polaroid camera.

\section{Duplex PCR Protocol for genotyping $C$. perfringens type A strains}

Both primer pairs described above were placed in the same reaction mix to create a Duplex-PCR assay capable of distinguishing between the chromosomal or plasmidic location of the cpe gene in type A strains (22). PCR amplification was carried out using $0.6 \mu \mathrm{M}$ of each primer used for "plasmidic-cpe" amplification and $0.8 \mu \mathrm{M}$ of each primer used for "chromosomal-cpe" amplification. Final reaction volume was $50 \mu$, containing the other mix reagents and template in equal concentrations as in the above amplifications. Cycling conditions were repeated as described above. Results were determined by $1.5 \%$ agarose gel 
electrophoresis. PCR samples were run at $80 \mathrm{~V}$ during $50 \mathrm{~min}$. Bands were viewed on a transilluminator and photographs were taken with a Polaroid camera.

\section{RESULTS}

\section{C. perfringens count}

Most probable number (MPN) in iron-milk medium.

Twenty six $C$. perfringens strains were isolated out of the total of 100 dehydrated soup samples analyzed (26\%). These 26 isolates

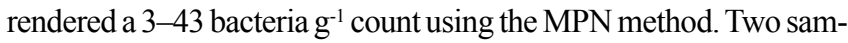
ples $(7.7 \%)$ surpassed the $10 \mathrm{~g}^{-1}$ limit established by the Argentine Food Code (CAA), showing 15 and $43 \mathrm{MPN} \mathrm{g}^{-1}$ (Art. 442). Four samples (15.4\%) almost reached the limit showing 9.2 $\mathrm{MPN} \mathrm{g}^{-1}$.

\section{Determination of the hygienic conditions of samples \\ Total aerobic bacteria count}

Total mesophilic aerobes rendered counts between $10^{2}$ and $10^{4}$ bacteria $\mathrm{g}^{-1}$. These results were found to fall within the CAA limits $\left(10^{5} \mathrm{~g}^{-1}\right)$ for this food.

\section{Total coliforms and E. coli investigation}

Twelve positive samples were found of the 63 examined (19\%) for the total coliforms reaction. The CAA does not limit these microorganisms for foods that are cooked. E. coli was not detected.

\section{In vitro production of enterotoxin \\ Enterotoxin assessment}

None of the assayed strains isolated from dehydrated soups produced enterotoxin, and thus were defined as non-enterotoxigenic strains.

\section{Correlation of the chromosomal location of the cpe gene and} spore heat-resistance in enterotoxigenic strains.

All studied enterotoxigenic strains (100\%) were heat-resistant at $80^{\circ} \mathrm{C}$ and $100^{\circ} \mathrm{C}$. Non-enterotoxigenic strains used as negative controls did grow after heating at $80^{\circ} \mathrm{C}$, but did not grow after heating at $100^{\circ} \mathrm{C}$.

\section{Protease activity determination}

\section{Kinetic results}

Protease activity kinetics in enterotoxigenic and non-enterotoxigenic strains

Kinetic results for the non-enterotoxigenic strain were plotted to show that the highest protease activity was reached at $0.5 \%$ of substrate (Fig. 1). Thus, this condition ( $0.5 \%$ substrate) was chosen to study protease activity in the 13 non-enterotoxigenic strains. The kinetic assay for the enterotoxigenic strain showed the same activity pattern as for the non-enterotoxigenic strain when rising substrate concentration: $0.5 \%$ showed highest protease activity (Fig. 2). This condition was also chosen to study protease activity in the 15 enterotoxigenic strains.

Protease activity determination in enterotoxigenic and nonenterotoxigenic strains

All assayed strains (100\%) showed protease activity. Enterotoxigenic strains showed higher protease activity than nonenterotoxigenic strains.

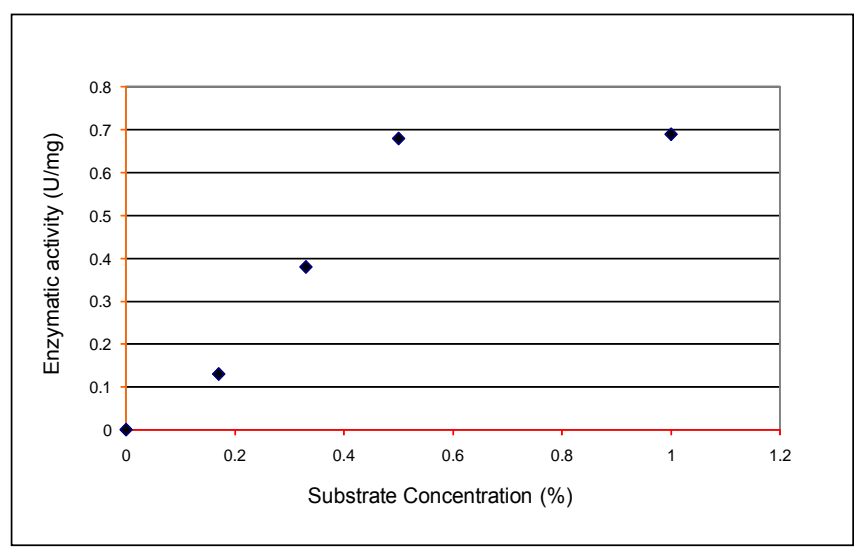

Fig. 1. Protease activity kinetics of a non-enterotoxigenic strain (NESL 13).

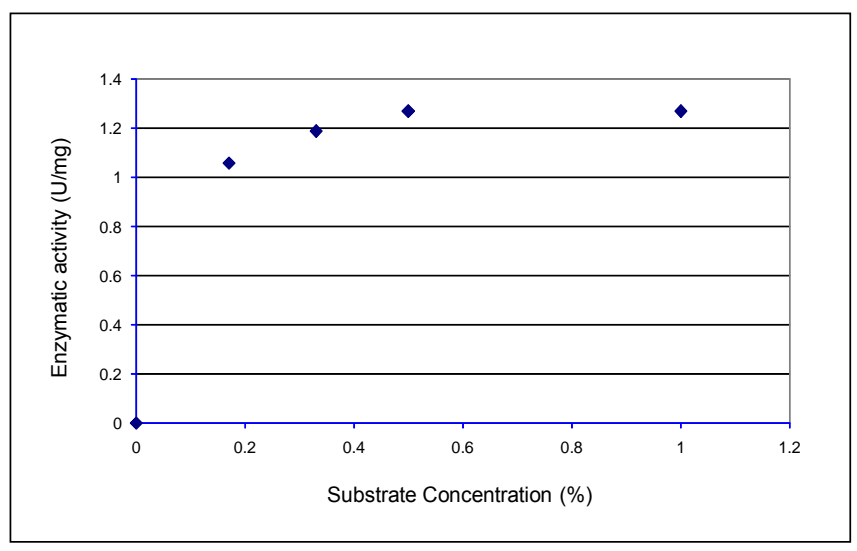

Fig. 2. Protease activity kinetics of an enterotoxigenic strain (ESL 3).

The 13 cpe-strains showed a mean Specific Activity $=0.22 \mathrm{U} /$ mg of protein, while the $15 \mathrm{cpe}+$ strains showed a mean Specific Activity $=0.3 \mathrm{U} / \mathrm{mg}$ of protein (Table 1, Fig. 3). Statistical results from the t-test, which assesses the probability associated with Student's t-test, showed a significant difference $<0.05$.

\section{Azoreductase activity determination}

All assayed strains (100\%) showed Azoreductase activity. Enterotoxigenic strains showed higher activity along with shorter times needed for reduction of the azo-compound: enterotoxigenic strains needed 6-24 hrs while non-enterotoxigenic strains needed 6-72 hrs.

PCR results for cpe gene detection on the chromosome or on the plasmid

The location for the cpe gene was determined by setting two standard PCRs and using primers targeted to the gene's possible location on the chromosome or on the plasmid. Enterotoxigenic strains previously isolated from meat foods, spices and seasonings were used. Both amplification products for each strain were seeded side-by-side in order to confirm the presence of the cpe gene on the chromosome or on the plasmid (Fig. 4). All 15 enterotoxigenic strains in study showed chromosomal location for the enterotoxin gene, as the amplification product was $\sim 2100$ bp (Fig. 5). 
Table 1: Specific Activity results of cpe- and cpe+ strains of C. perfringens

\begin{tabular}{|l|c|c|c|}
\hline $\begin{array}{l}\text { cpe- } \\
\text { strains }\end{array}$ & $\begin{array}{c}\text { Specific } \\
\text { Activity }\end{array}$ & $\begin{array}{c}\text { cpe+ } \\
\text { Strains }\end{array}$ & $\begin{array}{c}\text { Specific } \\
\text { Activity }\end{array}$ \\
\hline Strain & U/mg of prot. & Strain & U/mg of prot. \\
\hline NESL 13 & 0.149 & ESL 1 & 0.33 \\
\hline NESL 16 & 0.612 & ESL 2 & 0.27 \\
\hline NESL 22 & 0.249 & ESL 3 & 0.45 \\
\hline NESL 24 & 0.158 & ESL 4 & 0.23 \\
\hline NESL 43 & 0.168 & ESL 5 & 0.27 \\
\hline NESL 50 & 0.183 & ESL 6 & 0.27 \\
\hline NESL 53 & 0.173 & ESL 7 & 0.23 \\
\hline NESL 55 & 0.176 & ESL 8 & 0.41 \\
\hline NESL 60 & 0.176 & ESL 9 & 0.32 \\
\hline NESL 77 & 0.189 & ESL 10 & 0.23 \\
\hline NESL 85 & 0.200 & ESL 11 & 0.29 \\
\hline NESL 86 & 0.188 & ESL 12 & 0.23 \\
\hline NESL 88 & 0.221 & ESL 13 & 0.35 \\
\hline mean & 0.218 & ESL 14 & 0.23 \\
\hline & & ESL 15 & 0.36 \\
\cline { 3 - 5 } & & mean & 0.298 \\
\hline
\end{tabular}

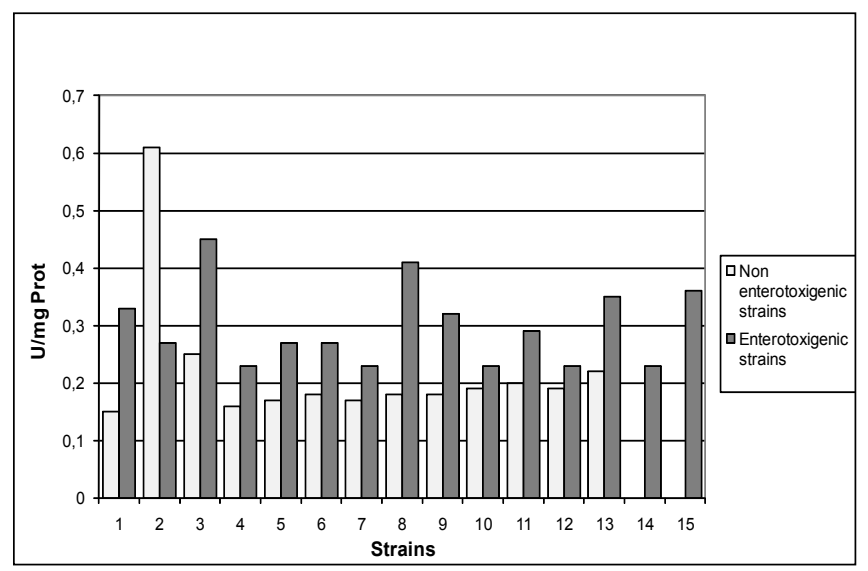

Fig. 3. Specific activity, protease determination. $X$ axis: strain group, Y axis: U/mg of proteins. Light grey: non-enterotoxigenic strains. Dark grey: enterotoxigenic strains.

\section{DISCUSSION}

The fact of having isolated $C$. perfringens from dehydrated soup samples did not represent an alarming issue since they were non-enterotoxigenic. Nevertheless, the literature indicates that soups come third in place as the most common source of C. perfringens after meat foods, spices and seasonings. In addition, the presence of this microorganism in food has been reviewed in the Argentine Food Code (56), which has set the upper limit at 10 spores gram $^{-1}$ (Art. 442) for dehydrated soups. Two samples have surpassed this limit (43 and $15 C$. perfringens $\mathrm{g}^{-1}$ ), and 4 other were almost reaching the limit $\left(9.2\right.$ C. perfringens $\left.\mathrm{g}^{-1}\right)$.

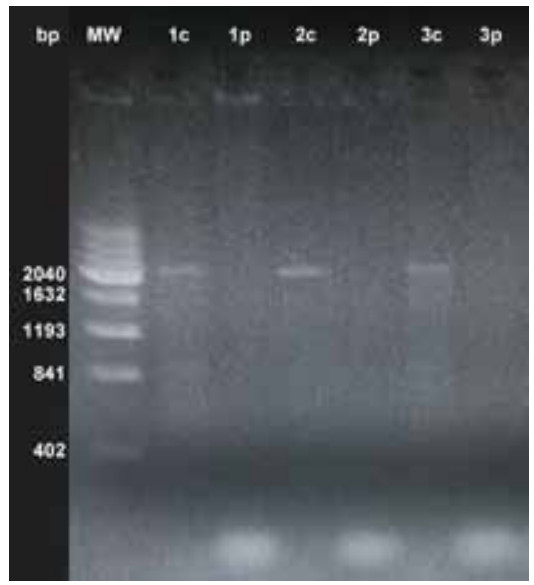

Fig. 4. MW: molecular weight markers. 1c, $2 c$ and 3c: amplification products from strains 1, 2 and 3 using chromosomallocation primers. $1 p, 2 p$ and $3 p$ : amplification products from strains 1, 2 and 3 using plasmidic-location primers.

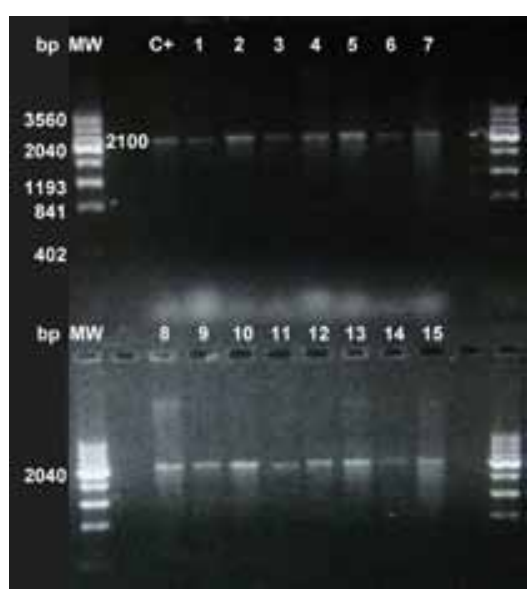

Fig. 5. MW: molecular weight markers. C+: positive control. Enterotoxigenic strains 1-15, PCR amplification using chromosomal-location primers.

It is important to perceive the risk associated with heating and reheating the spore contaminated food later. In this scenario, germinated spores can find an adequate environment for multiplication and can therefore reach suitable concentrations for food poisoning, even when the initial load was lower than the limit set by the CAA (8-10).

The assays assessing the sanitary-hygienic quality of dehydrated soups revealed that total mesophilic aerobes were within the limits set by the CAA $\left(10^{5} \mathrm{~g}^{-1}\right)$ for this food. However, coliforms were found in 12 samples, one sample surpassing the maximum allowed limit $\left(10^{3} \mathrm{~g}^{-1}\right)$. E. coli was not isolated. In general terms, it can be stated that the sanitary-hygienic quality of dehydrated soups is good and, although the incidence of $C$. perfringens was low, there is a potential risk of food poisoning in case of inappropriate food preparation and handling.

The presence and expression of the cpe gene is fundamental in producing gastrointestinal symptoms (13). The critical point in enterotoxin (CPE) determination is enterotoxin expression. As is known, this toxin is produced only upon sporulation and, if the environment is not good enough for this, a possible false negative 
can take place $(15,16)$. However, in addition to the positive and negative controls from the RPLA kit, we use two enterotoxigenic strains as positive controls for the culture medium. The medium of choice was the Modified Tórtora (Tm) medium.

$C$. perfringens may be present in vegetables, spices and seasonings that were used as additives to the different soup varieties described in the literature. Wild strains are understood to be common enterotoxin-producers (3).

Election of an adequate technique to determine enzymatic activity is crucial. Although not much literature was found on $C$. perfringens protease activity, the option of choice was azocasein because it is widely used as a substrate in this type of assays for a large number of genera and species (35-37). Due to results obtained from preliminary assays that compared the modified Domínguez and Cejudo technique to the modified Brock technique, the former one was chosen. This technique does not use $\mathrm{NaOH}$ and has the advantage of requiring shorter incubation times, which results in overall reduction in time and costs.

According to the kinetic study using a cpe+ and a cpe-strain, and different substrate concentrations, tube 3 - presenting $0.5 \%$ substrate concentration and corresponding to the highest enzymatic activity - was chosen.

All strains were shown to have protease activity. Results from protease activity and specific activity reveal that there is a quantitative difference between $c p e-$ and $c p e+$ strains that can be correlated to higher pathogenicity in enterotoxigenic strains.

Concerning C. perfringens azoreductase activity, the dye Direct Blue 15 was chosen. Although it is known that this compound and its cleavage products are extremely toxic, it renders a useful substrate to study and determine the presence and/or activity of enzymes bearing azoreductase activity (57). Currently, several bio-discoloring systems are in development. These systems use microorganisms in order to lower toxicity and contamination - - not only ecological, but also visual $\square$ generated from Direct Blue 15 usage $(58,59)$. In our study, all assayed strains showed azoreductase activity, though enterotoxigenic strains showed higher activity and shorter times for Direct Blue 15 discoloring. The presence of azoreductase in the $C$. perfringens strains indicated high virulence and thus correlated the high pathogenicity of the enterotoxigenic strains to the higher azoreductase activity in the strains (44).

The PCR assay that determines plasmidic or chromosomal location of the cpe gene gives an idea of the possible reservoirs for potential outbreaks caused by $C$. perfringens in association to food (22).

Both standard PCR assays using primers that locate the cpe gene in the plasmid or in the chromosome have the advantage of being capable of identifying $C$. perfringens cpe + from poorly sporulating cultures that can be otherwise taken as false negatives by serological methods.

The duplex PCR assay has additional advantages such as lowering reagent costs and spent time by combining both primer pairs described above in one single reaction. Also, this assay demonstrated that these strains, isolated from the studied food, carry the cpe gene in the chromosome. Although the food in study was not related to any outbreak, the fact of the cpe gene having chromosomal location raises worries concerning the heat resistance feature present in these types of strains and the risk of potentially causing food poisoning. It is to note that in our area there is no epidemiological data on food poisoning by $C$. perfringens because this illness develops without complications and practically no routine clinical tests are performed.

Upon learning about the cpe gene location in a cpe+ strain and of the relationship "chromosomal cpe gene / heat-resistant strain" and "plasmidic cpe gene / heat-sensitive strain", stress should be laid upon the importance of low temperature storage conditions for food as well as correct heating and/or cooking in prevention of food poisoning caused by $C$. perfringes type A.

Isolation of $C$. perfringens carrying a plasmid-borne cpe gene from feces from individuals affected by food poisoning is an atypical case; nevertheless, it supports the need for cooking food properly, preserving hygiene at all times and to not discard heat-sensitive strains of $C$. perfringens as possible causal agents of food poisoning.

Development of a multiplex PCR assay using primers that distinguish insertion sequences (IS) located downstream from the plasmid-borne cpe gene is a very important advancement because it brings out the possibility of studying the prevalence of different ISs and, thus, represents another tool for unveiling the mechanisms of horizontal transmission between $C$. perfringens strains. The hypothesis of plasmid transmission by conjugation mechanisms is supported (26). The ability to transfer the plasmid from cpe+ strains to cpe- strains, and thus transform the latter into enterotoxigenic strains, is a point to be taken into account as the presence of enterotoxigenic $C$. perfringens may convert $c p e-$ strains from normal flora into $c p e+$, consequently causing a gastrointestinal illness.

\section{CONCLUSIONS}

1. The incidence of $C$. perfringens in the dehydrated soup samples was found to fall within the limit values stated in the literature. Enterotoxigenic strains of $C$. perfringens were not detected in these samples.

2. In general, the tested soups had good hygienic conditions, as $E$. coli was not detected.

3. The studied foods represent a risk for health, if the particular conditions required for microorganism proliferation are met.

4. The fact of finding azoreductase and protease activity represents the presence of other important virulence factors of $C$. perfringens, that must be taken into account when handling food contaminated with $C$. perfringens.

5 . There is a relation between virulence factors and enterotoxigenicity of the strains, which implies a high risk.

6. The presence of the cpe gene in chromosomal location indicates a higher risk of suffering food poisoning illness when consuming food contaminated with $C$. perfringens.

\section{ACKNOWLEDGEMENTS}

This work was supported by Secretaría de Ciencia y Técnica of Universidad Nacional de San Luis. Project 8803.

\section{REFERENCES}

1. Golden NJ, Crouch EA, Latimer H, Kadry AR, Kause J. Risk assessment for Clostridium perfringens in ready-to-eat and partially cooked meat and poultry products. J Food Prot. 2009 Jul;72(7):1376-84. 
2. Avenaud P, Marais A, Monteiro L, Le Bail B, Bioulac Sage P, Balabaud C, et al. Detection of Helicobacter species in the liver of patients with and without primary liver carcinoma. Cancer. 2000 Oct 1;89(7):1431-9.

3. Rodríguez E, Gamboa Mdel M, Vargas P. Clostridium perfringens in raw and cooked meats and its relation with the environment in Costa Rica. Arch Latinoam Nutr. 2002 Jun;52(2):155-9. (In Spanish.)

4. Basualdo JA, Coto C, de Torres R. Biomedical Microbiology. 2nd ed. Buenos Aires: Atlante; 2006.

5. Sting R. Detection of beta 2 and major toxin genes by PCR in Clostridium perfringens field isolates of domestic animals suffering from enteritis or enterotoxaemia. Berl Munch Tierarztl Wochenschr. 2009 SepOct;122(9-10):341-7.

6. Ando Y, Tsuzuki T, Sunagawa H, Oka S. Heat resistance, spore germination, and enterotoxigenicity of Clostridium perfringens. Microbiol Immunol. 1985;29(4):317-26

7. Barnes EM, Ingram M. The effect of redox potential on the grown Clostridium welchii strains isolated from horse muscle. J Appl Bact. 1956; $19: 177-8$

8. Guzmán AMS, Micalizzi B, Torres Pagano CE, Giménez DF. Incidente of Clostridium perfringens in fresh sausages in Argentina. J Food Prot. 1990;53:173-5

9. Rey Arrans JC, Aranda Ramírez C, Pedrosa Arias M, Conde Valero A, Castilla Pedregosa I. Food hygiene in catering establishments of a tourism zone of Andalusia. Medicina de Familia (And). 2002;3(2):108-13 (In Spanish.)

10. Hernández Herrero MM, Roig Sagués AX, Jerez JJ. Food security in the World. Autonomous University of Barcelona. Boletín Oficial de la Provincia de Barcelona. 2003;155:1-128. (In Spanish.)

11. Nauerby B, Pedersen K, Madsen M. Analysis by pulsed-field gel electrophoresis of the genetic diversity among Clostridium perfringens isolates from chickens. Vet Microbiol. 2003 Jul 17;94(3):257-66.

12. Johansson A, Aspan A, Bagge E, Båverud V, Engström BE, Johansson KE. Genetic diversity of Clostridium perfringens type A isolates from animals, food poisoning outbreaks and sludge. BMC Microbiol. 2006 May 31;6:47

13. Stagnitta PV, Micalizzi B, de Guzmán AMS. Prevalence of enterotoxigenic Clostridium perfringens in meats in San Luis, Argentina. Anaerobe. 2002 Oct;8(5):253-8

14. Park KB, Labbé RG. Proteolysis of Clostridium perfringens type A enterotoxin during purification. Infect Immun. 1990 Jun;58(6):1999-2001.

15. Kokai-Kun JF, Songer JG, Czeczulin JR, Chen F, McClane BA. Comparison of Western immunoblots and gene detection assays for identification of potentially enterotoxigenic isolates of Clostridium perfringens. J Clin Microbiol. 1994 Oct;32(10):2533-9.

16. dela Cruz WP, Gozum MM, Lineberry SF, Stassen SD, Daughtry M, Stassen NA, et al. Rapid detection of enterotoxigenic Clostridium perfringen by real time fluorescence resonance energy transfer PCR. J Food Prot. 2006 Jun;69(6):1347-53

17. Augustynowicz E, Gzyl A, Slusarczyk J. Detection of enterotoxigenic Clostridium perfringens with a duplex PCR. J Med Microbiol. 2002 Feb;51(2):169-72.

18. Sparks SG, Carman RJ, Sarker MR, McClane BA. Genotyping of enterotoxigenic Clostridium perfringens fecal isolates associated with antibiotic-associated diarrhea and food poisoning in North America. J Clin Microbiol. 2001 Mar;39(3):883-8.

19. McClane BA, Chakrabarti G. New insights into the cytotoxic mechanisms of Clostridium perfringens enterotoxin. Anaerobe. 2004 Apr;10(2):107-14.

20. Aguilera MO, Stagnitta PV, Micalizzi B, de Guzmán AM. Prevalence and characterization of Clostridium perfringens from spices in Argentina. Anaerobe. 2005 Dec;11(6):327-34.

21. Miyamoto K, Wen Q, McClane BA. Multiplex PCR genotyping assay that distinguishes between isolates of Clostridium perfringens type A carrying a chromosomal enterotoxin gene (cpe) locus, a plasmid cpe locus with an IS1470-like sequence, or a plasmid cpe locus with an IS1151 sequence. J Clin Microbiol. 2004 Apr;42(4):1552-8.

22. Wen Q, Miyamoto K, McClane BA. Development of a duplex PCR genotyping essay for distinguishing Clostridium perfringens type A isolates carrying chromosomal enterotoxin (cpe) genes from those carrying plasmid-borne enterotoxin (cpe) genes. J Clin Microbiol. 2003 Apr;41(4):1494-8.

23. Czeczulin JR, Collie RE, McClane BA. Regulated expression of Clostridium perfringens enterotoxin in naturally cpe-negative type $\mathrm{A}, \mathrm{B}$, and $\mathrm{C}$ isolates of C. perfringens. Infect Immun. 1996 Aug;64(8):3301-9.

24. Petit L, Gibert M, Popoff MR. Clostridium perfringens: toxinotype and genotype. Trends Microbiol. 1999 Mar;7(3):104-10.
25. Miyamoto K, Chakrabarti G, Morino Y, McClane BA. Organization of the plasmid cpe locus in Clostridium perfringens type A isolates. Infect Immun. 2002 Aug;70(8):4261-72. Erratum in: Infect Immun. 2003 Mar;71(3):1611.

26. Deguchi A, Miyamoto K, Kuwahara T, Miki Y, Kaneko I, Li J, et al. Genetic characterization of type A enterotoxigenic Clostridium perfringens strains. PLoS One. 2009 May 19;4(5):e5598.

27. Cornillot E, Saint-Joanis B, Daube G, Katayama S, Granum PE, Canard $\mathrm{B}$, et al. The enterotoxin gene (cpe) of Clostridium perfringens can be chromosomal or plasmid-borne. Mol Microbiol. 1995 Feb;15(4):639-47.

28. Miki Y, Miyamoto K, Kaneko-Hirano I, Fujiuchi K, Akimoto S. Prevalence and characterization of enterotoxin gene-carrying Clostridium perfringens isolates from retail meat products in Japan. Appl Environ Microbiol. 2008 Sep;74(17):5366-72.

29. Li J, McClane BA. Further comparison of temperature effects on growth and survival of Clostridium perfringens type A isolates carrying a chromosomal or plasmid-borne enterotoxin gene. Appl Environ Microbiol. 2006 Jul;72(7):4561-8.

30. Collie RE, McClane BA. Evidence that the enterotoxin gene can be episomal in Clostridium perfringens isolates associated with non-food-borne human gastrointestinal diseases. J Clin Microbiol. 1998 Jan;36(1):30-6.

31. Tanaka D, Isobe J, Hosorogi S, Kimata K, Shimizu M, Katori K, et al. An outbreak of food-borne gastroenteritis caused by Clostridium perfringens carrying the cpe gene on a plasmid. Jpn J Infect Dis. 2003 Jun;56(3):1379. Erratum in: Jpn J Infect Dis. 2004 Jun;57(3):following p 135.

32. Grant KA, Kenyon S, Halford-Maw R, Pettitt E, McLauchlin J. Location of the enterotoxin gene in strains of Clostridium perfringens associated with gastroenteritis. 16th European Congress of Clinical Microbiology and Infectious Diseases Nice, France, 1-4 2006. Clin Microbiol Infect. 2006;S4:1644.

33. Braun P, Fehlhaber C, Klug C, Kopp K. Investigations into the activity of the enzymes produced by spoilage-causing bacteria: a possible basis for improved shelf-life estimation. Food Microbiol. 1999;16(5):531-40.

34. Allison C, Macfarlane GT. Regulation of protease production in Clostridium sporogenes. Appl Environ Microbiol. 1990 Nov;56(11):3485-90.

35. Poilane I, Karjalainen T, Barc MC, Bourlioux P, Collignon A. Protease activity of Clostridium difficile strains. Can J Microbiol. 1998 Feb;44(2):157-61

36. Zarnowski R, Connolly PA, Wheat LJ, Woods JP. Production of extracellular proteolytic activity by Histoplasma capsulatum grown in Histoplasma-macrophage medium is limited to restriction fragment length polymorphism class 1 isolates. Diagn Microbiol Infect Dis. 2007 Sep;59(1):39-47.

37. Brock FM, Forsberg CW, Buchanan-Smith JG. Proteolytic activity of rumen microorganisms and effects of proteinase inhibitors. Appl Environ Microbiol. 1982 Sep;44(3):561-9.

38. Macfarlane GT, Allison C, Gibson SA, Cummings JH. Contribution of the microflora to proteolysis in the human large intestine. J Appl Bacteriol. 1988 Jan;64(1):37-46.

39. McDonel JL. Clostridium perfringens toxins (type A, B, C, D, E). Pharmacol Ther. 1980;10(3):617-55.

40. Shimizu T, Shima K, Yoshino K, Yonezawa K, Shimizu T, Hayashi H. Proteome and transcriptome analysis of the virulence genes regulated by the VirR/VirS system in Clostridium perfringens. J Bacteriol. 2002 May;184(10):2587-94

41. Park KB, Labbé RG. Isolation and characterization or extracellular proteases of Clostridium perfringens type A. Curr Microbiol. 1991;23(4):2159 .

42. Park KB, Labbé RG. Purification and characterization of intracellular proteases of Clostridium perfringens type A. Can J Microbiol. 1991 Jan;37(1):19-27.

43. Rafii F, Cerniglia CE. Comparison of the azoreductase and nitroreductase from Clostridium perfringens. Appl Environ Microbiol. 1993 Jun;59(6):1731-4.

44. Rafii F, Franklin W, Cerniglia CE. Azoreductase activity of anaerobic bacteria isolated from human intestinal microflora. Appl Environ Microbiol. $1990 \mathrm{Jul} ; 56(7): 2146-51$.

45. Nakamura J, Kubota Y, Miyaoka M, Saitoh T, Mizuno F, Benno Y. Comparison of four microbial enzymes in Clostridia and Bacteroides isolated from human feces. Microbiol Immunol. 2002;46(7):487-90.

46. Medvedev ZA, Crowne HM, Medvedeva MN. Age related variations of hepatocarcinogenic effect of azo dye (3'-MDAB) as linked to the level of hepatocyte polyploidization. Mech Ageing Dev. 1988 Dec;46(1-3):159-74.

47. Rafii F, Park M, Gamboa da Costa G, Camacho L. Comparison of the metabolic activities of four wild-type Clostridium perfringens strains 
with thein gatifloxacin-selected resistant mutants. Arch Microbiol. 2009 Dec;191(12):895-902.

48. Raffi F, Cerniglia CE. Localization of the azoreductase of Clostridium perfringens by immuno-electron microscopy. Curr Microbiol. 1993;27(3):143-5.

49. St John WD, Matches JR, Wekell MM. Use of iron-milk medium for enumeration of Clostridium perfringens. J Assoc Off Anal Chem. 1982;65(5):1129-33.

50. Man JC. The probability of most probable numbers. Eur J Appl Microbiol. 1975;1:67-78.

51. Tórtora JC. Alternative medium for Clostridium perfringens sporulation. Appl Environ Microbiol. 1984 May;47(5):1172-4.

52. Sarker MR, Shivers RP, Sparks SG, Juneja VK, McClane BA. Comparative experiments to examine the effects of heating on vegetative cells and spores of Clostridium perfringens isolates carrying plasmid genes versus chromosomal enterotoxin genes. Appl Environ Microbiol. 2000 Aug;66(8):3234-40.

53. Dominguez F, Cejudo FJ. Characterization of the endoproteases appearing during wheat grain development. Plant Physiol. 1996 Nov;112(3):1211-7.
54. Lowry OH, Rosebrough NJ, Farr AL, Randall RJ. Protein measurement with the Folin phenol reagent. J Biol Chem. 1951 Nov;193(1):265-75.

55. Rafii F, Ruseler-Van Embden JG, Asad YF. Azoreductase and nitroreductase activity of bacteria in feces from patients with an ileal reservoir. Dig Dis Sci. 1997 Jan;42(1):133-6.

56. Argentine Food Code (CAA), Chapter 6, Art 442, Res 125, 21.1.82. (In Spanish.)

57. Zou W, Cerniglia CE, Chen H. Azoreductase in Staphylococcus aureus. Curr Protoc Toxicol. 2009;41:4.28.1-4.28.9.

58. Pazarlioglu NK, Urek RO, Ergun F. Biodecolourization of Direct Blue 15 by immobilized Phanerochaete chrysosporium. Process Biochem. 2005;40(5):1923-9.

59. Kumar K, Devi SS, Krishnamurthi K, Dutta D, Chakrabarti T. Decolorisation and detoxification of Direct Blue-15 by a bacterial consortium. Bioresour Technol. 2007 Nov;98(16):3168-71.

Received November 24, 2009 Accepted in revised form October 21, 2010 